\title{
Can "Monkey Business" Resolve the Most Contentious Issue in the Convention on Biological Diversity?
}

\author{
Gabriel Marrero-Girona \\ Department of Economics, University of Puerto Rico-Río Piedras \\ PO Box 23345, San Juan, PR 00931-345, USA \\ E-mail: gabrielmarrero@yahoo.com
}

Prof. Joseph Henry Vogel (Corresponding author)

Department of Economics, University of Puerto Rico-Río Piedras

PO Box 23345, San Juan, PR 00931-345, USA

E-mail: josephvogel@usa.net

Received: November 1, 2011

Accepted: December 12, 2011

Published: March 1, 2012

doi:10.5539/ijps.v4n1p55

URL: http://dx.doi.org/10.5539/ijps.v4n1p55

Indirect support has been provided by the National Science Foundation IGERT Grant (0801577), the Australian Research Council Grant (LX0881935) and the International Barcode of Life. Any opinions, findings, conclusions or recommendations expressed are those of the authors and do not necessarily reflect the views of the NSF, ARC or $i B O L$.

\begin{abstract}
Access to genetic resources and "fair and equitable" sharing of benefits (ABS) is the elusive objective of the 1992 United Nations Convention on Biological Diversity. At the tenth Conference of the Parties, long-standing differences were immortalized through the capacious language of the "Nagoya Protocol [NP] on the Fair and Equitable Sharing of Benefits Arising from the Utilization of Genetic Resources." Although the NP does not resolve any contentious issue, the opposing narratives of scientist-as-hero and scientist-as-villain are reconciled through "mutually agreed terms" (MAT). The uncontested concept appears twenty-five times and transparency, thrice. An alternative narrative from the economics of information explains how "confidential business information," subsumed in MAT, frustrates any "fair and equitable" royalty rate. Insights from psychology facilitate the brokerage of a fair and equitable rate and the US Commonwealth of Puerto Rico lends itself to a pilot project on the International Regime on ABS.

Keywords: Bioprospecting, Cognitive policy, Genetruthing, iBOL, International regime on ABS, Framing, Nagoya Protocol, Puerto Rico

\section{Introduction}

The United Nations celebrates the 20th anniversary of the Convention of Biological Diversity (CBD) in June 2012. The CBD is a framework agreement under continuous negotiation through the Conference of the Parties (COP). Without doubt, the most contentious issue of the CBD has been "access to genetic resources" and "the fair and equitable sharing of benefits arising from the utilization of genetic resources." The unwieldy phrases in quotes are known by the acronym ABS. Over two decades and ten COPs, the words "fair and equitable" faded from discussions by a factor of four (see Table 1). The qualifiers were only resuscitated in COP10 as evidenced in the official title "The Nagoya Protocol [NP] on the Fair and Equitable Sharing of Benefits Arising from the Utilization of Genetic Resources." Despite self-congratulation by the Secretariat and the developing world, NP does not settle ABS (Kamau E. C., Fedder B. \& Winter G., 2010). It is yet another international agreement to disagree. Especially disconcerting to the economist is the absence of a royalty rate --- the only real measuring rod of benefits --- in the marathon of negotiations. The issue of fixing a percentage $(0.5 \%, 5 \%, 50 \%$ ?) can only be inferred from a circumlocution about "minimum requirements" in Material Transfer Agreements (MTAs)
\end{abstract}


(Cabrera Medaglia, 2010). Perhaps unexpectedly, cognitive science can elucidate the exclusion of royalties in the dominant narratives and shed light on what would be a fair and equitable rate. "Monkey business," understood both literally and figuratively, helps frame the ongoing morass.

\section{Urgency as an Underlying Theme of All ABS Narratives}

In The Diversity of Life, E.O. Wilson estimates in a "maximally optimistic conclusion" that "the number of species doomed each year is 27,000. Each day it is 74, and each hour 3" (Wilson, 1992, p. 280). Doing the math since the CBD was ratified on 29 December 1993, some 473,328 species would have become extinct by 29 December 2011. Ten years after Diversity, Wilson qualified such exercises in The Future of Life: "Although it is possible to predict species extinction for the near future --- say, over the next decade or two --- such a projection is impossible for the more distant future. The obvious reason is that the trajectory depends on human choice" (Wilson, 2002, p. 101).

Economics is all about "human choice" and most economists would wholeheartedly welcome Wilson's question "How Much is the Biosphere Worth?" (Wilson, 2002, p. 103). However, they would be nonplussed by the answer Wilson offers: "No one can guess the full future value of any kind of animal, plant, or microorganism" (p. 113). Despite well-publicized attempts to do just that (Costanza et al., 1997), Wilson is right: valuation will always be fragmentary. For ABS, we see this in the seemingly worthless microbes associated with rotten wood (Figure I) and live trees (Figure II). Rather than boldly estimate a total value, another approach exists: the design of institutions that enable a market for novel enzymes, antibiotics, and so on. Unfortunately, such hope has been dashed over the criteria of "fair and equitable" in benefit-sharing agreements. Very few countries have achieved ABS implementation (Carrizosa et al. 2004), which indicates that the CBD has indeed become an impediment to the emergence of markets in novel enzymes, etc.

\section{Inhibition of the Economics-of-information Narrative}

The texts of both the CBD and the NP define several key terms; "fair and equitable" are not among them. Nevertheless, one definition bears directly on "fair and equitable": "genetic resource." According to Article 2 of the CBD, "genetic resources" are "material" even though they are immaterial or, more properly phrased, information. Genes as information can be traced to Francis Crick's famous "central dogma of molecular biology" (1970). For material goods, competition promotes efficiency and equity; for information goods, competition promotes neither (Samuelson \& Nordhaus, 2005). The exception of information goods from the standard economics analysis inheres to the high fixed costs of research and development and the low marginal costs of reproduction. Without protection from competitors, creators cannot recoup the fixed costs of their creations. Why spend vast sums to create something if everyone can cheaply copy it? Time-limited monopoly rights are the solution.

In as much as genes are information --- a sequence of nucleotide bases that can be copied --- the analogy with intellectual property is really a homology. Conservationists cannot recoup the opportunity costs of conservation if anyone can trade freely in the same natural information, usually geographically dispersed. Why conserve a vast habitat if you can take out a few samples? Oligopoly rights over natural information are the analog to the monopoly rights over artificial information. Such framing of ABS also extends to enforcement. Similar to artificial information, the illicit flow of natural information cannot be impeded physically. The fence around information must be metaphorical, i.e., a legal instrument. So, the economics-of-information narrative ends with analogous institutions: intellectual property has TRIPs and WIPO; genetic resources should have an International Regime on ABS under the Secretariat to the UN CBD.

The economics of information has been studiously ignored over twenty years of ABS discussions (Ruiz 2010, Vogel et al. 2011). Why? One is tempted to return to the wisdom of Wilson "Trust me. Physics is difficult even for physicists" (2001, p. xvii). Like physics, economics is difficult. Is it too difficult? An answer to that indelicate question is suggested in the United Nations Framework Convention on Climate Change (UN FCCC) and the Kyoto Protocol (KP). The economics of "additionality" in business-as-usual scenarios for the FCCC is far more obtuse than the economics of information for the CBD. Moreover, some delegates of the COP to the FCCC are also delegates of the COP to the CBD. Probing the history of the two conventions, one notes that the COPs of the FCCC were guided by concomitant reports from the Intergovernmental Panel on Climate Change under the lead authorship by Graciela Chichilnisky, a world-class economist who later crafted the language of the carbon market in the KP (Chichilnisky \& Sheeran, 2009).

The evidence of economic thinking in the FCCC indicates that its absence in the CBD does not lie in the difficulty of economics. We respectively consider an alternative explanation that derives from the dominance orders of primates. From decades of observing the political behavior of chimpanzees and humans, Frans de Waal 
perceives in the latter that "the persuasive power of logic is surprisingly limited" (2005, p. 197). Social hierarchies within the UN delegations coalesced around the established narratives in the early to mid-1990s: economic in the case of the FCCC and non-economic in the CBD. Any swap of the narrative this late in the game of the CBD would disrupt the established hierarchies even though many delegates agree in private that the dominant narrative is indeed wrong (Note 1). Al Gore's quotation of Upton Sinclair applies not just to Big Oil and Coal: "It's difficult to get a man to understand something if his salary depends upon his not understanding it" (2006, pp. 266-267).

\section{Dominant and Divergent Narratives: Scientist as Hero and Scientist as Villain}

Cognitive linguist George Lakoff writes that "frames trump facts" (2006, p. 13), where frames are understood as "cognitive structures" (2008, p. 22) and narratives, "the frames that tell stories" (2008, p. 250). Two narratives grip the COPs that frame ABS discussions. The first is identified with the developed countries who view order and progress through science and technology. The scientist is a hero and the CBD, interference. Nowhere does this narrative resonate more than in the question of taxonomy. Intoning exasperation, stakeholders from the developed world ask: How are we to know what to conserve when we can't even collect specimens? Condescension abounds (Buck \& Hamilton, 2011, pp. 48-49). When accused of inappropriate access to genetic resources, scientists joke about being "Rafi'ed," a neologism whose etymology lies in the acronym of the Rural Advancement Foundation Institute since re-named Erosion, Technology, Concentration (ETC) (McManis, 2004, p. 460).

The countervailing narrative to science-as-hero is identified with the developing countries. Progress is seen through publicly funded science and technology transfer. The scientist is villain only when he or she seeks patents for the utilization of genetic resources. Because the protection afforded by the CBD has been lackluster, cynicism manifests itself and sometimes dramatically so. In the main hallway of the Conference Centers to the COPs, ETC awards the "Captain Hook Prize" for biopiracy. The Master of Ceremonies struts in swashbuckling costume and feigns a period English accent; small crowds form to much merriment.

Lakoff emphasizes that "[i]f empathy is natural, then self-interest is anything but the whole story" $(2008$, p. 203). Despite the passion of the dominant and divergent ABS narratives, twenty years of negotiation have cultivated empathy among the delegates, especially from countries that are both providers and users of genetic resources. Most delegations recognize the problems of wanton biopiracy and bureaucratic interference. Diplomatically conditioned, they seek consensus over "fair and equitable sharing of benefits." Precisely because "fair and equitable" are assumed subjective --- beyond rational analysis --- the concept of "mutually agreed terms" is not contested. The logic runs: if terms are mutually agreed, then they must be fair and equitable --- QED --- no party would agree to something unfair and inequitable.

\section{Back to the Economics-of-information Narrative: Unfair and Inequitable Royalties}

The unimportance accorded royalties can be deduced from a simple word count of the "Bonn Guidelines on Access and Benefit Sharing as Related to Genetic Resources" adopted at COPVI in 2002 and subsequently cut and pasted into the Annex of the NP. The "r" word appears twice among 8,000 other words. To date no megadiverse country has agreed to massive MTAs according to the Bonn Guidelines. The existence of dominance hierarchies in politics is again explanatory. The race-to-the-bottom royalties of $1 \%$ or less invite understandable derision (Edmonds Institute, 2009) and derision augurs poorly for the sustainability of political life. So, the solution is selective non-disclosure of the benefits: bells and whistles for the technology transfers, foreign traineeships, and laboratory equipment but blustering indignation over anyone's temerity to enquire about the "confidential business information" of royalties! (Note 2). Again, the "find" key in MicroSoft Word is useful. In the text of the NP, "mutually agreed terms" appears 25 times and transparency, thrice. Lakoff highlights the role of repetition in cognitive policy: "When a word or phrase is repeated over and over for a long period of time, the neural circuits that compute its meaning are activated repeatedly in the brain...Because thought occurs at the neural level, most of our thinking is not available to conscious introspection" (2006, p. 10).

\section{Overlaying "Monkey Business" to the Economics-of-information Narrative}

Monkey business is not just a metaphor for the shenanigans of biodiplomacy. The lifetime work of the remarkable Jane Goodall (1986) shows just how unremarkable are humans in the broader context of primate behavior. The notions of "fair and equitable" exhibit patterns across taxonomic orders. Primatologists Elizabeth Brosnan and Frans de Waal show that when caged Cebus apella (Capuchin monkeys) are rewarded unequally for equal tasks, the disadvantaged party throws a fit. "We placed two monkeys side by side, exchanging with both of them twenty-five times in a row, first with one, then the other, and so on. If both received cucumber, this was called equity. In this situation, the monkeys exchanged all the time, happily eating the food. But if we gave one 
of them grapes while keeping the other on cucumber, things took an unexpected turn. This was called inequity...Upon noticing their partner's salary raise, monkeys who had been perfectly willing to work for cucumber suddenly went on strike...hurling pebbles and sometimes even the cucumber slices out of the test chamber" (pp. 217-218).

Twenty years of rejected ABS proposals from around the world are the metaphorical equivalent of projectile pebbles and cucumbers. Admittedly, our analogy is a poor one: the cucumber rather than the grape is not as inferior as $1 \%$ or less royalty on a potentially billion-dollar biotechnology.

What would any self-respecting monkey want? The experiments suggest no less than a 50-50 split of profits with the biotechnology industry. But now "monkey business" must be interpreted metaphorically. The calculation of profit margin on any product depends wholly on how programmed (fixed) costs are assigned within the firm. N.B. a 50-50 split of zero is still zero. To avoid creative accounting, benefit sharing should be negotiated on the return to sales of the industry. Geoffrey Heal has calculated the return as $16 \%$ in the case of pharmaceuticals (2008, Table 5.1), meaning that a 50-50 split would be $8 \%$ of sales. Nevertheless, caveats are still in order. Any industry that enjoys monopoly patents is prone to the principal-agent problem; the agents (senior management) compensate themselves lavishly at the expense of the principals (diffused stockholders). "Despite a year fraught with manufacturing issues and drug recalls,...the top ten 10 CEO Pharma salaries in 2010 ranged from 10 to 29 million USD" (Hollis \& Teichert, 2010). So, the 16\% return on sales may actually underestimate the potential profitability deriving from the genetic resource. Moreover, the firm can pass a large chunk of the royalty on to the consumer through higher prices. How much is a question of elasticities of supply and demand. Vogel has long argued that $15 \%$ is a good starting point for negotiating the royalty for ABS (Southgate, 1997, p. 43-44).

No matter what royalty ultimately obtains, the shares among claimants must also be worked out. Again, "equal pay for equal work" resonates. The dictum implies that work is measured in units and "equal" modifies units: "equal pay for equal [units of] work." For example, the Amazon basin is shared by nine countries with Brazil holding $60 \%$, Peru 13\%, and the other seven countries the remaining 27\% (Portal Brasil, 2010). Equal pay for equal work would imply equal royalties per unit of conserved habitat of the species bioprospected. At a $15 \%$ royalty for a gene sequence found throughout the basin but nowhere else, Brazil would enjoy a royalty payment of $9 \%$ of sales, Peru $2 \%$, and so on.

Prudence dictates a pilot project for any large-scale endeavor. One can imagine property holders of patches of remnant forests as if each were a country. The property owner of a large patch would be analogous to Brazil; a small patch, Surinam. However, to run the experiment one runs up against the CBD. For the 193 countries that have ratified the $\mathrm{CBD}$, any pilot project on the International Regime would require an ABS agreement. Only countries that have not ratified the CBD can avoid the endless hassles. As Carrizosa et al. note in the introduction to their survey of ABS implementation: "[G]enetic resources found on private lands [in the US] are controlled by the owner unless protected by the Endangered Species Act or other relevant federal or state laws. The [de facto] owner of genetic resources is relatively free to negotiate ABS conditions with the bioprospector" (2004, p. 11). The irony of the comparative advantage of the non-ratified countries or better said, country, compounds. Within US jurisdiction, the most extensive place of tropical biodiversity fragmented on private lands is probably the Commonwealth of Puerto Rico, often berated as the oldest colony in the world (Monge, 1999), Tuaisceart Éireann notwithstanding.

\section{7. "Nothing is Less Real than Realism"}

The famous quote from American modernist Georgia O'Keeffe ends with "It is only by selection, by elimination, by emphasis that we get at the real meaning of things" (Messinger, 1988, p. 45). A photo of a landowner and forest patch in Puerto Rico does not get at the meaning of a pilot project for the International Regime on ABS (Figure III). Only illustrations crafted "by selection, by elimination, by emphasis...get at the real meaning." Figure IV shows how data are collected from diverse patches of Dacryodes excelsa (Tabonuco, Family Burseraceae). From each patch, microorganisms are sequenced to find potentially useful genes that may overlap among the three hypothetical property owners. However, the share of royalties will change with changing land use or identification of more landowners with the same genetic resource. Satellite imagery can detect the changes in land use while predictive habitat modeling can identify potential claimants. Nevertheless, no one should be denied or rewarded royalties based on a satellite image or a mathematical prediction. "Groundtruthing" in Geographic Information Systems is required as well as something analogous at the molecular level. We call it "genetruthing": confirmation from sequencing a barcode gene from samples that were collected in the field. The lower quadrant of Figure V illustrates how the relative claim to royalties changes with changing land use and new claimants. 
Billion-dollar technologies from natural products chemistry and drug discovery are not fantasy. One thinks of the Thermus aquaticus (Taq) that made possible polymerase chain reaction (PRC) (Brock, 1997) and the broad swath of pharmaceutical research that now derives from Epipedobates tricolor (Angerer, 2011). But who should get what when the genetic resource is ubiquitous? For a block-buster biotechnology, the $\$ 64,000$ question becomes a $\$ 64$ million dollar question to which industry will reply: "no one". Although ubiquitous genetic resources are not threatened with extinction, exemption would be disastrous for other resources that are indeed threatened (Vogel, 2007). As Milton Friedman argued in a different context "Try selling a product that someone else is giving away!" (1980). Perhaps a more appropriate example is the Argentine intellectual property law that prohibits musicians from donating their music to filmmakers (Sociedad Argentina de Autores y Compositors de Música).

Who should receive royalties collected on ubiquitous genetic resources? The efficient and equitable answer is the gargantuan database that enables distribution for the non-ubiquitous genetic resources (Vogel, 1994). A technological infrastructure of classified species exists that seems custom-made to the task: The International Barcode of Life (Stoeckle \& Hebert, 2008; Schindel, 2010). In other words, iBOL enables ABS through information on species and their geographic distribution; ABS enables iBOL through financing from ubiquitous genetic resources (Vogel, 2010) (Figure VI). Genome Canada projects a six-year budget of iBOL at CAN \$100 million (Genome Canada, 2011, p.8).

\section{Conclusion}

The history of economic thought can illuminate transdisciplinary approaches. Nowhere is this more evident than access to genetic resources and the fair and equitable sharing of benefits. Long before George Lakoff framed public policy in terms of neural circuitry, John Maynard Keynes wrote in the Preface to The General Theory of Employment, Interest and Money "The difficulty lies, not in the new ideas, but in escaping from the old ones, which ramify, for those brought up as most of us have been, into every corner of our minds" (1936, p. viii).

Keynes revolutionized economics by integrating alternative behavioral assumptions (e.g., wage rigidities, money illusion and animal spirits) into the very foundations of economics. Only recently has empiricism shown just how perspicacious was Keynes (Pech \& Milan, 2009). World War II was an unplanned experiment in Keynesian fiscal stimulus that worked, decisively. Similarly efficient and equitable was the post-war international financial system (Bretton Woods) that Keynes designed. Our history-of-thought analogy is almost complete and lacks just a few details. "Equal pay for equal work" has been corroborated in rigorous experiments with other primates. It resonates across human cultures while integrating easily with evolutionary psychology (Saad, 2007, 2011a \& 2011b). Once ABS is so contextualized, the emerging International Regime can fix a significant rate and facilitate distribution of royalties fairly, equitably, and efficiently. The despair and defeat of bilateral ABS negotiations will give way to hope and success. The solution is reminiscent of Keynes and Bretton Woods.

How much longer must we wait until the COP assimilates the economics-of-information narrative? Patches of Tabonuco still stand tall in Puerto Rico but Wilson's extinction clock is ticking, ticking, ticking.

\section{Acknowledgment}

Research assistance has been provided by Verónica M. Pacheco-Ortiz, Nora Álvarez-Berríos and Omar Oduardo-Sierra. Comments to early drafts by Barbara A. Hocking, Manuel Ruiz, Maritza Stanchich were especially appreciated.

\section{References}

Angerer, K. (2011). Frog tales - on poison dart frogs, epibatidine, and the sharing of biodiversity. Innovation: The European Journal of Social Science Research, 24(3), 353-369. http://dx.doi.org/10.1080/13511610.2011.592061

Brock, T. B. (1997). The value of basic research: discovery of Thermus aquaticus and other extreme thermophiles. Genetics, 146, 1207-1210.

Buck, M., \& Hamilton, C. (2011). The Nagoya Protocol on access to genetic resources and the fair and equitable sharing of benefits arising from their utilization to the convention on biological diversity. Review of European Community \& International Environmental Law, $20 \quad$ (1), 47-61. http://dx.doi.org/10.1111/j.1467-9388.2011.00703.x

Cabrera Medaglia, J. (2010). The political economy of the international ABS regime negotiations. ICTSD Programme on Natural Resources, Natural Resources, International Trade and Sustainable Development, Issue Paper No.2. International Centre for Trade and Sustainable Development, Geneva, Switzerland. [Online] 
Available: http://ictsd.org/downloads/2011/02/cabrera_1_web_6-re1.pdf

Carrizosa, S., Brush, S. B., Wright, B. D., \& McGuire, P. E. (2004). Accessing biodiversity and sharing the benefits: lessons from implementation of the Convention on Biological Diversity. IUCN, Gland, Switzerland and Cambridge, UK. [Online] Available:

http://www.grcp.ucdavis.edu/publications/docABSPacRim/ABSPacRimwww.pdf

Chichilnisky, G., \& Sheeran, K. A. (2009). Saving Kyoto. London: New Holland Publishers.

Costanza, R., D'arge, R., de-Groot, R., Farber, S., Grasso, M., Hannon, B., Limburg, K., Naeem, S., O'Neill, R.V., Paruelo, J., Raskin, R.G., Sutton, P., \& Van-Den-Belt, M. (1997). The value of the world's ecosystem services and natural capital. Nature, vol 387, 253-260. [Online] Available: http://www.uvm.edu/giee/publications/Nature_Paper.pdf

Crick, F. (1970). Central dogma of molecular biology. Nature, vol 227, 561-563. [Online] Available: http://profiles.nlm.nih.gov/ps/access/SCBCCH.pdf

Edmonds Institute. (1999). Press Release: Mexico's genetic heritage sold for twenty times less than the US got in Yellowstone. [Online] Available: http://www.biotech-info.net/genetic_heritage.html

Friedman, M. (1980). What's wrong with our schools? From Free to choose: A personal statement. [Online] Available:

http://www.edchoice.org/The-Friedmans/The-Friedmans-on-School-Choice/What-s-Wrong-with-Our-Schools-.a $\operatorname{spx}$

Genome Canada. (2011). Coporate Plan 2011-12. [Online] Available: http://www.genomecanada.ca/medias/PDF/EN/CorporatePlan2011-12-english.pdf

Goodall, J. (1986). The chimpanzees of Gombe. Boston: Belknap Press.

Gore, A. (2006) An inconvenient truth. New York: Rodale Books.

Heal, G. (2008). The three measures of return for the pharmaceutical industry and five other industries in pharmaceuticals and corporate responsibility. In When principles pay: corporate social responsibility and the bottom line. New York: Columbia University Press. [Online] Available: http://cup.columbia.edu/media/3663/heal-table5.1.pdf

Hollis L., \& Teichert E. (2010). Top 10 Pharma CEO Sales of 2010. Annual Report, FiercePharma. [Online] Available: $\mathrm{http}: / / \mathrm{www}$. fiercepharma.com/special-reports/top-10-pharma-ceo-salaries 2010?sms_ss $=$ twitter\&at_xt $=4$ db90abdda0a1243,0

Kamau, E. C., Fedder, B., \& Winter, G. (2010). The Nagoya Protocol on access to genetic resources and benefit sharing: what is new and what are the implications for provider and user countries and the scientific community? Law, Environment and Development Journal 6/3, 51-65. [Online] Available: http://www.lead-journal.org/content/10246.pdf

Keynes, J. M. (1936). The general theory of employment, interest and money. London: Macmillian.

Lakoff, G. (2006). Whose freedom? New York: Farrar, Straus and Giroux.

Lakoff, G. (2008). The political mind. New York: Penguin.

McManis, C. R. (2004). Fitting traditional knowledge protections and biopiracy claims into the existing intellectual property and unfair competition framework. In Burton Ong (Ed.) Intellectual property and biological resources. Singapore: Marshall Cavendish.

Messinger, L. M. (1988). Georgia O'Keeffe. New York: The Metropolitan Museum of Art/Thames and Hudson Inc.

Monge, T. (1999). Puerto Rico: The trials of the oldest colony in the world. New Haven: Yale University Press.

Pech, W., \& Milan, M. (2009). Behavioral economics and the economics of Keynes. Journal of Socio-Economics, 38(6), 891-902. http://dx.doi.org/10.1016/j.socec.2009.06.011

Portal Brasil. (2010). Environment. [Online] Avalable: http://www.brasil.gov.br/sobre/environment/the-amazon/the-amazon/br_template_completo?set_language=en

Ruiz, M. (2010). The museum as a vehicle for considered judgments on access and benefit sharing. In J. Vogel (Ed.) The museum of bioprospecting, intellectual propery and the public domain. London: Anthem Press.

Saad, G. (2007). The evolutionary bases of consumption. Mahwah, NJ: LEA/Psychology Press. 
Saad, G. (2011a). The consuming instinct. New York: Prometheus Books.

Saad, G. (Ed.) (2011b). Evolutionary psychology in the business sciences. New York: Springer.

Samuelson, P. A., \& Nordhaus, W. D. (2005). ECONOMICS (18 $8^{\text {th }}$ ed.). New York: McGraw-Hill Irwin.

Schindel, D. (2010). Biology without borders. Nature, 467, 779-781. http://dx.doi.org/10.1038/467779a

Sociedad argentina de autores y compositores de música (S.A.D.A.I.C.). (1969, September). Ley 17.648, Decreto 5.146/69. [Online] Available: http://www.colegiosn.com/textos/legis_nac/prop intelec/5146.htm

Southgate, D. (1997). Alternatives for habitat protection and rural income generation. Washington, D.C.: InterAmerican Development Bank, No. ENV-107.

Stoeckle M. Y., \& D. N. Hebert. (2008, October). Barcode of Life. Scientific American, 82-88. http://dx.doi.org/10.1038/scientificamerican1008-82

Ten Kate, K., \& S.A. Laird. (1999). The commercial use of biodiversity. London: Earthscan Publications, Ltd.

Vogel, J. H. (1994). Genes for sale. New York: Oxford University Press.

Vogel, J. H. (2007). From the 'tragedy of the commons' to the 'tragedy of the commonplace': analysis and synthesis through the lens of economic theory. In Charles McManis (Ed.), Biodiversity \& law (pp. 115-136). London: Earthscan.

Vogel, J. H. (2009). The economics of the Yasuni Initiative. London: Anthem Press.

Vogel, J. H. (2010, March). iBOL as an Enabler of ABS and ABS as an Enabler of iBOL. Proceedings of the Seminar 'Barcoding of Life: Society and Technology Dynamics - Global and National Perspectives, 38-47, $\mathrm{UNEP} / \mathrm{CBD} / \mathrm{WG}-\mathrm{ABS} / 9 / \mathrm{INF} / 15$. [Online] Available: http://www.cbd.int/doc/meetings/abs/abswg-09-3rd/information/abswg-09-3rd-inf-15-en.pdf

Vogel, J. H. Álvarez-Berríos, N. Quiñones-Vilche, N. Medina-Muñiz, J. L. Pérez-Montes, D. Arocho-Montes, A. I. Vale-Merniz, N. Fuentes-Ramirez, R. Marrero-Girona, G. Valcárcel Mercado, \& E. Santiago-Rios, J. (2011). The economics of information, studiously ignored in the Nagoya Protocol on access and benefit sharing. Law Environment and Development, 7(1), 47-74. [Online] Available: http://www.lead-journal.org/content/11052.pdf

Wilson, E.O. (1992). The diversity of life. New York: W.W. Norton \& Company.

Wilson E.O. (2001). Introduction: Life is a narrative. In Bilger, B. (Ed.) The best American science \& nature writing 2001. New York: Houghton Mifflin Company.

Wilson, E.O. (2002). The future of life. New York: Vintage Books.

\section{Notes}

Note 1. Different problems will require different framings to achieve their respective purpose. We advocate an economics narrative only for the UN CBD. For the UN FCCC, non-equilibrium thermodynamics makes greater sense of climate change and the policies necessary to stabilize $\mathrm{CO}_{2} \mathrm{e}$ emissions (Vogel, 2009).

Note 2. The second author queried a party to an MTA about the royalty rate at the Latin American Workshop on Access to Genetic Resources, sponsored by the World Resource Institute (May 1999, Cancún, Mexico). Ten years later, a similar situation arose in an email exchange with the mailing list of experts for the "non-commercial research" follow-up to the Report of meeting with ABS co-chairs of the Secretariat of the CBD, Montreal (July 2009). In first instance, the indignation of the queried party startled the Spanish-English interpreters at the event; in the second, a tongue-in-cheek disclosure established that the royalty rate fell somewhere between 0.00501 and 0.14999 . 
Table 1. The qualifiers "fair and equitable" muted in ABS citations

\begin{tabular}{|c|c|c|}
\hline & Phrase Googled (8:30PM GMT 18 October 2011) & Hits \\
\hline \multirow[t]{2}{*}{ Exact language from the CBD: } & $\begin{array}{c}\text { "the fair and equitable sharing of benefits arising out of the } \\
\text { utilization of genetic resources" (US spelling) }\end{array}$ & 25,200 \\
\hline & $\begin{array}{l}\text { "the fair and equitable sharing of benefits arising out of the } \\
\text { utilisation of genetic resources" (British spelling) }\end{array}$ & 8,100 \\
\hline \multirow[t]{2}{*}{ Synonymous language: } & $\begin{array}{l}\text { "access to genetic resources and the fair and equitable sharing } \\
\text { of benefits" }\end{array}$ & 74,200 \\
\hline & $\begin{array}{c}\text { "access to genetic resources and fair and equitable benefit } \\
\text { sharing" }\end{array}$ & 9,970 \\
\hline Total of Qualified Language & & 97,470 \\
\hline \multirow[t]{2}{*}{ Truncated language: } & $\begin{array}{l}\text { "access to genetic resources and } \\
\text { sharing of benefits" }\end{array}$ & 28,000 \\
\hline & $\begin{array}{l}\text { "access to genetic resources and } \\
\text { benefit sharing" }\end{array}$ & 320,000 \\
\hline Total of truncated language & & 348,00 \\
\hline $\begin{array}{l}\text { Truncated Language/Qualified } \\
\text { Language }\end{array}$ & & 3.57 \\
\hline
\end{tabular}

The Taxonomy of a Metagenome: potentially useful groups in rotten wood

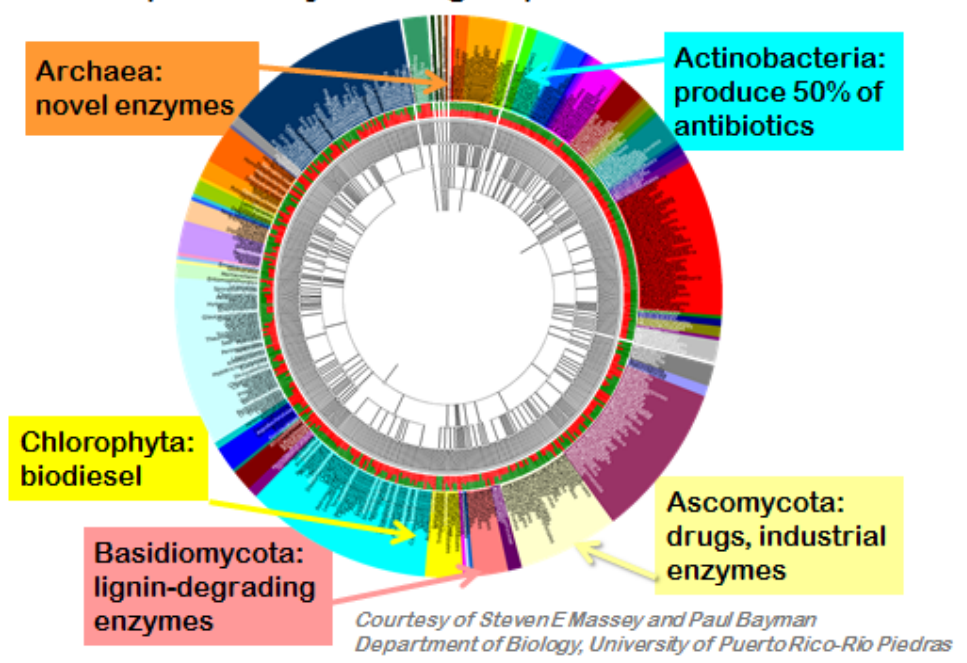

Figure 1. The taxonomy of metagenome: potentially useful groups in rotten wood 


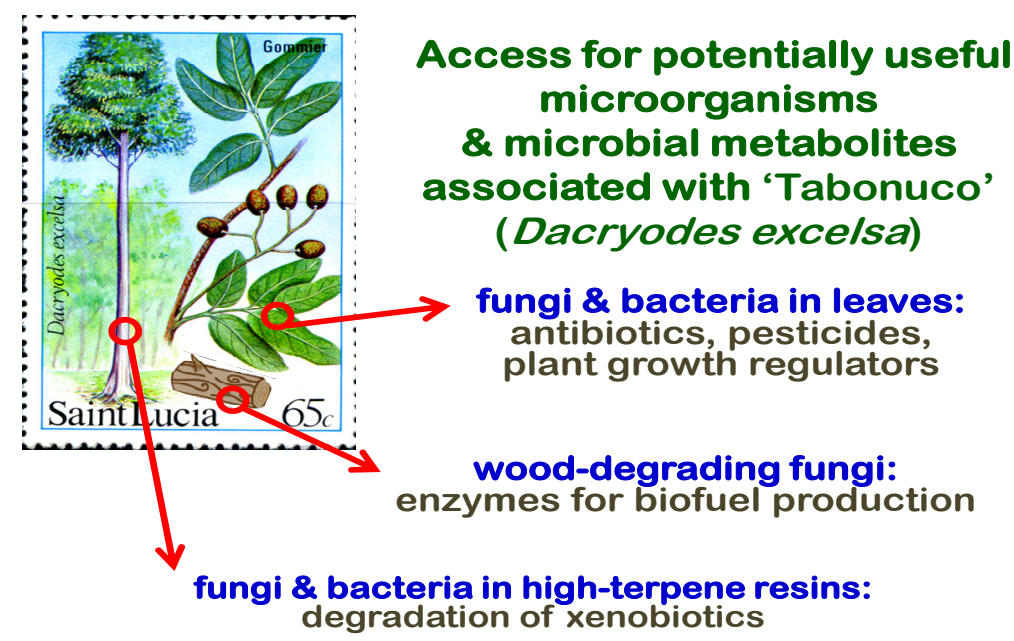

Figure 2. Access for potentially useful microorganisms \& microbial metabolites associated with "Tabonuco" (Darcyodes excelsa)

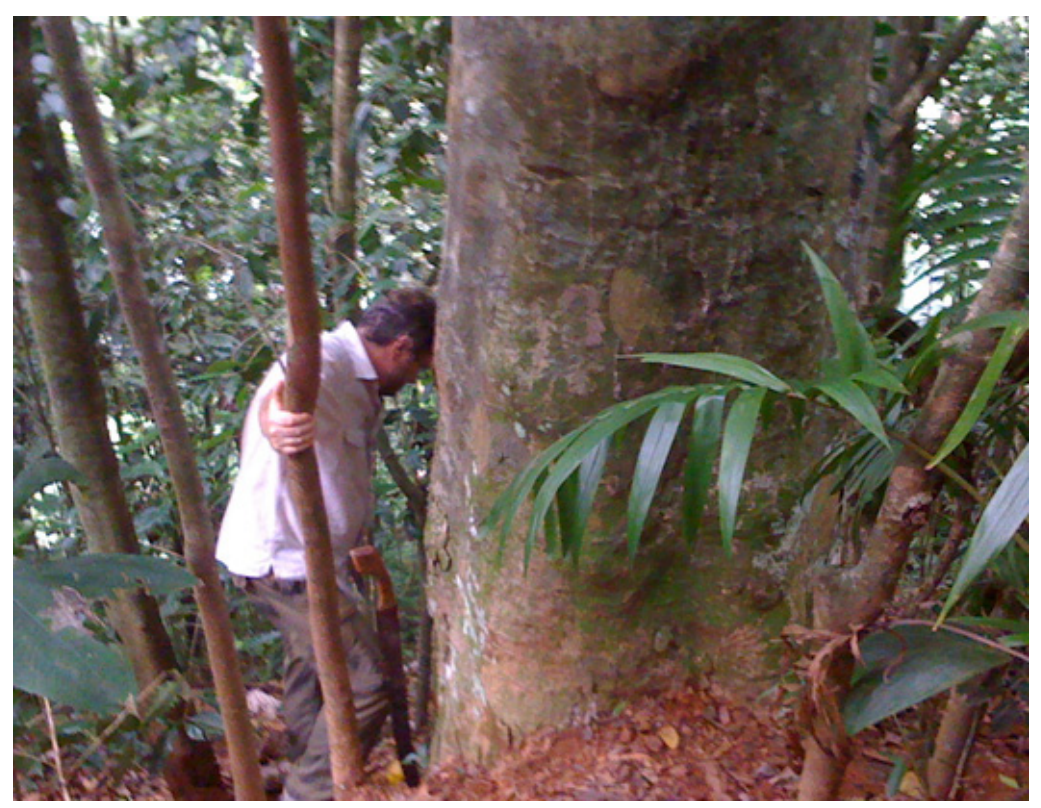

Figure 3. Mature specimen of D. excelsa (Tabonuco, Family Burseraceae) at Hacienda Verde, Utuado, Puerto Rico, a forty-acre biogeographic island owned by Miguel Rico, shown in photo.

Credit: Joseph Henry Vogel, 2009 


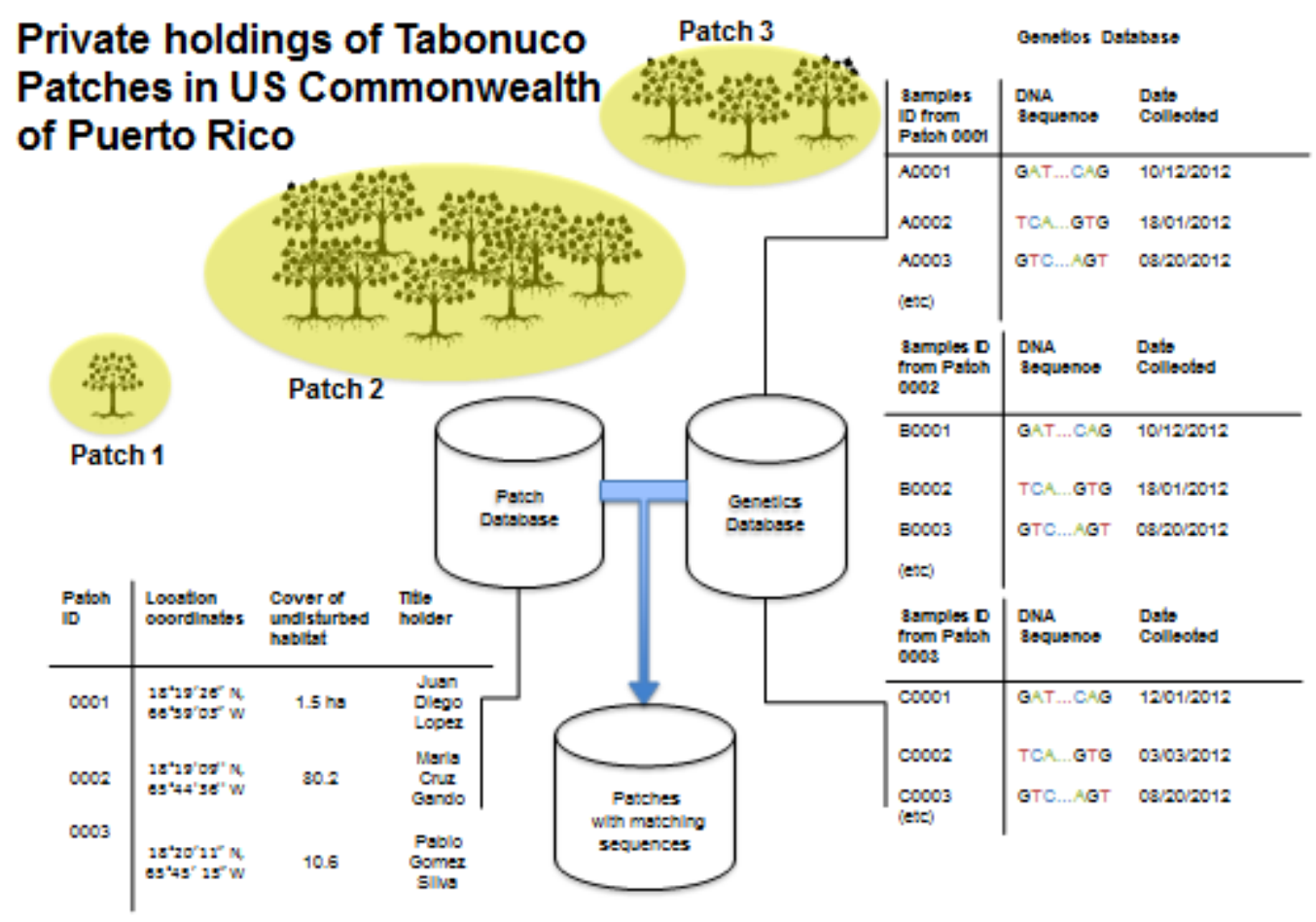

Figure 4. Private holdings of Tabonuco patches in US commonwealth of Puerto Rico

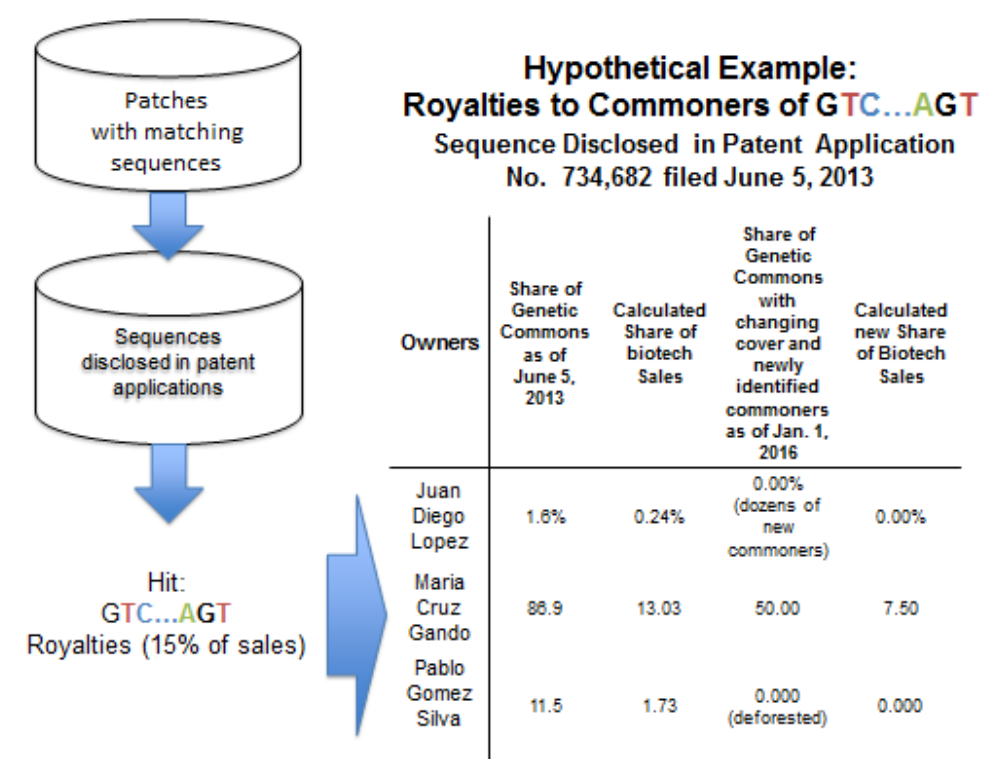

Figure 5. Hypothetical example: royalties to commoners of GTC...AGT 


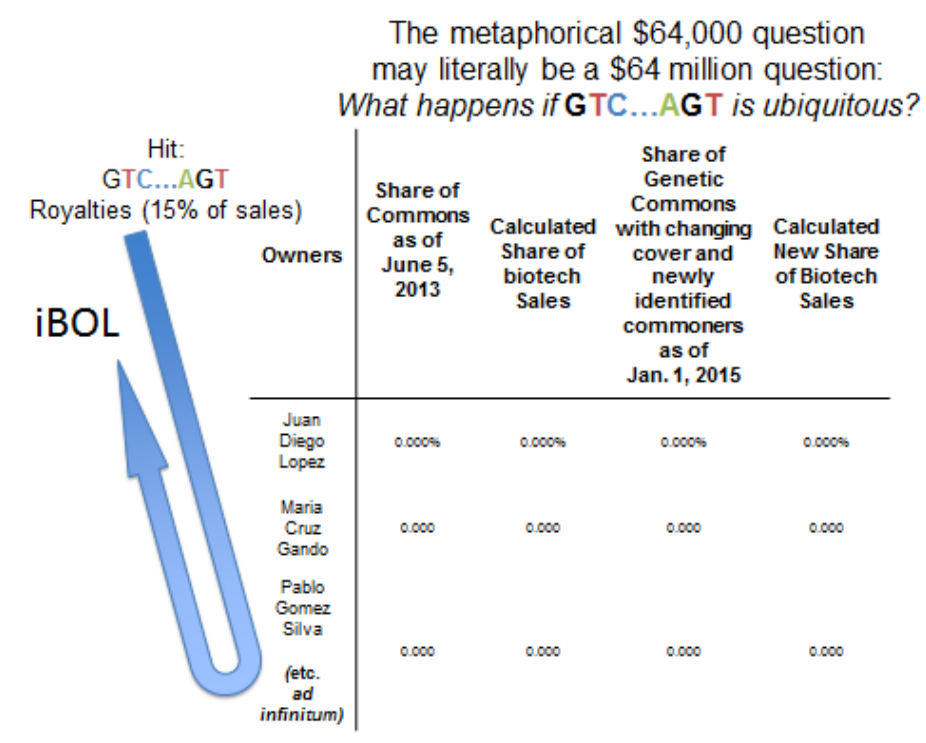

Figure 6. The metaphorical $\$ 64,000$ question may literally be a $\$ 64$ million question: What happens if GTC...AGT is ubiquitous? 